\title{
Erythrocyte Acid Phosphatase Polymorphism and Haemolysis
}

\author{
EGIDIO BOTTINI, PAOLA LUCARELLI, VITTORIA BASTIANON, \\ and FULVIA GLORIA
}

National Research Council Centre for Evolutionary Genetics (Department of Genetics, School of Science, University of Rome) and Department of Paediatrics, School of Medicine, University of Rome, Italy

An association between haemolytic favism and erythrocyte acid phosphatase phenotype has been reported by our group (Bottini et al, 1971).

More recently we have carried out a retrospective study on some erythrocyte polymorphic enzymes in a number of subjects who had been admitted to our hospital during the first few days of life for jaundice. In all babies serum bilirubin was of indirect type and the maximum level of serum bilirubin recorded ranged from 6 to $30 \mathrm{mg} \%$ (mean $16 \mathrm{mg}$ ). The group is heterogeneous including full-term infants compatible in the blood group systems with their mothers (subjects with a G6PD deficiency were excluded), incompatible full-term infants with negative Coombs test in whom jaundice appeared after the first day of life, and a few infants (compatible and incompatible) with birth weight below $2500 \mathrm{~g}$.

Received 24 July 1972.
The data on acid phosphatase are reported in Table I together with those of G6PD-deficient subjects which had had haemolytic favism. In all groups the distribution of acid phosphatase phenotypes is different from the respective controls. A constant feature is the excess of CA phenotype in both G6PD-deficient subjects with favism and nonenzymopoenic subjects with neonatal jaundice.

The variability in the capacity to conjugate and excrete bilirubin by the neonatal liver is very important in conditioning the level of serum bilirubin. However, it is known that the life span of red cells from newborn infants is about two- -0 thirds of that of normal adults and that even a slights increase in the haemolytic rate, not readily evidento by clinical standard tests, may be sufficient to cause a marked increase of serum bilirubin in the first few days of life (Pearson, 1967). It is also known that fetal red blood cells are very susceptible to the oxidative injury (Oski and Naiman, 1966) and that

TABLE I

DISTRIBUTION OF ACID PHOSPHATASE PHENOTYPES IN SUBJECTS WITH FAVISM OR NEONATAL JAUNDICE

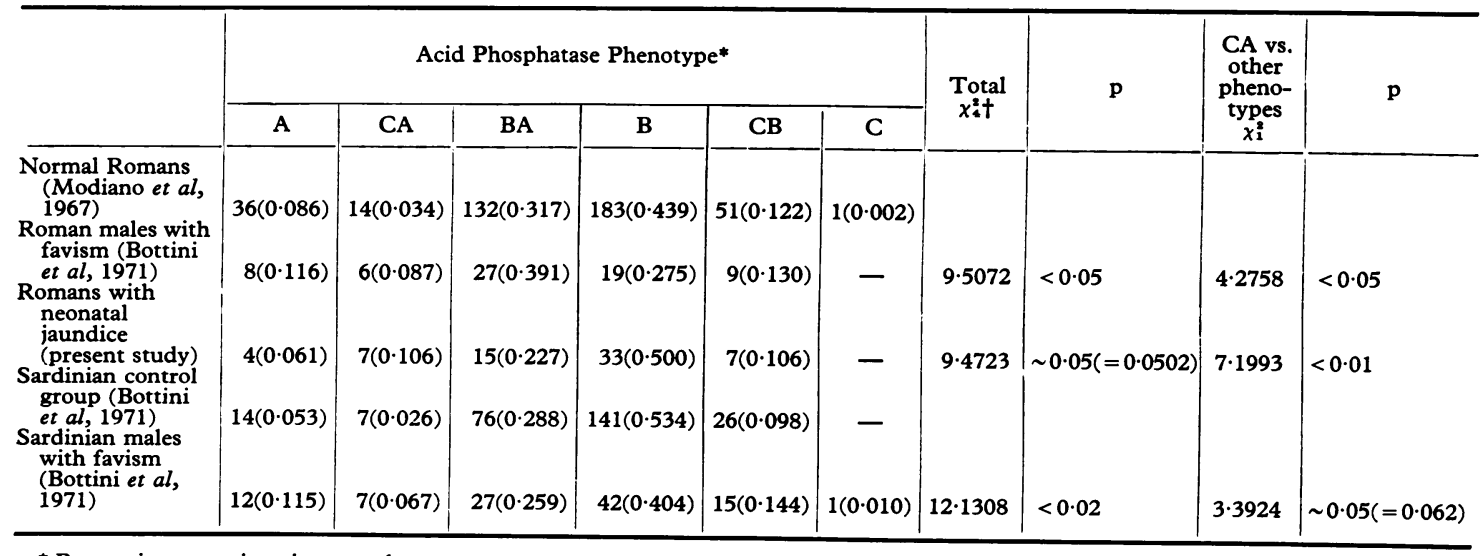

* Proportions are given in parentheses.

t Phenotype $C$ was associated with CB for calculations of $\chi^{2}$. 
during incubation in vitro with acetylphenylhydrazine, the stability of acid phosphatases in red cells from newborn infants is significantly lower compared to that in red cells from their mothers (Bottini et al, 1970).

The present observation may be regarded as a further suggestive evidence in favour of the hypothesis that acid phosphatase plays an important role in red cell destruction. Our data seem to indicate that CA phenotype has the highest risk of manifestations of clinical relevance.

We would like to thank Professor Harry Harris and Dr Peter L. Workman for helpful discussion.
REFERENCES

Bottini, E., Lucarelli, P., Agostino, R., Palmarino, R., Businco, L., and Antognoni, G. (1971). Favism: association with erythrocyte acid phosphatase phenotype. Science, 171, 409-411.

Bottini, E., Lucarelli, P., Tucciarone, L., Carapella, E., and Palmarino, R. (1970). In vitro effect of acetylphenylhydrazine on acid phosphatases of fetal red blood cells. Biology of the Neonate, 15, 57-60.

Modiano, G., Filippi, G., Brunelli, F., Frattaroli, W., Siniscalco, M., Palmarino, R., and Santolamazza, C. (1967). Studies on red cell acid phosphatases in Sardinia and Rome. Absence of correlation with past malarial morbidity. Acta Genetica et Statistica Medica, 17, 17-28.

Oski, F. A. and Naiman, J. L. (1966). Hematologic Problems in the Newborn, edited by A. J. Schaffer. Saunders, Philadelphia and London.

Pearson, H. A. (1967). Life-span of the fetal red blood cell. fournal of Pediatrics, 70, 166-171. 